\title{
The strontium isotopic composition of Maastrichtian and Danian chalk
}

\author{
NIELS OLUF JøRGENSEN AND OLE LARSEN
}

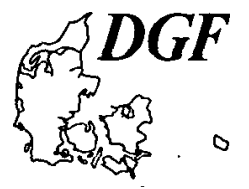

\begin{abstract}
Jørgensen, N. O. \& Larsen, O.: The strontium isotopic composition of Maastrichtian and Danian chalk. Bull. geol. Soc. Denmark, vol. 28, pp. 127-129. Copenhagen, February 22nd, 1980. htps://doi.org/10.37570/bgsd-1979-28-15

The isotopic composition of strontium has been measured in 22 samples of Maastrichtian and Danian chalk from various localities in the Danish region. The chalk is an extremely pure biogenic carbonate sediment. The material examined includes bulk samples as well as individual bryozoan skeletons. The ${ }^{87} \mathrm{Sr} /{ }^{86} \mathrm{Sr}$ ratios obtained were all within the analythical error of the value 0.7075 supporting this values as the isotopic composition of sea water at Late Cretaceous and Early Tertiary time.
\end{abstract}

N. O. Jørgensen and O. Larsen, Geologisk Centralinstitut, Ostervoldgade 10,DK-1350 København K., Denmark, October 23th, 1979.

Studies of the strontium isotopic composition of ancient marine carbonate sediments have demonstrated that the ${ }^{87} \mathrm{Sr} /{ }^{86} \mathrm{Sr}$ ratio of sea water has varyied systematically during Phanerozoic time (Peterman et al. 1970, Veizer and Compston 1974). Due to the long residence time of strontium in the oceans (at present $19 \times 10^{6} \mathrm{yr}$ ) compared to the mixing rate for ocean water (ab- out $10^{3} \mathrm{yr}$ ) sea water must have been isotopically homogeneous during a major part of the earth history. Detailed investigations of pure marine carbonates from selected areas thus contribute to the exact fixation of the curve of ${ }^{87} \mathrm{Sr} /{ }^{86} \mathrm{Sr}$ variation through geologic time (e.g. Tremba et al. 1975, Faure et al. 1978).

The present study supplements existing data by

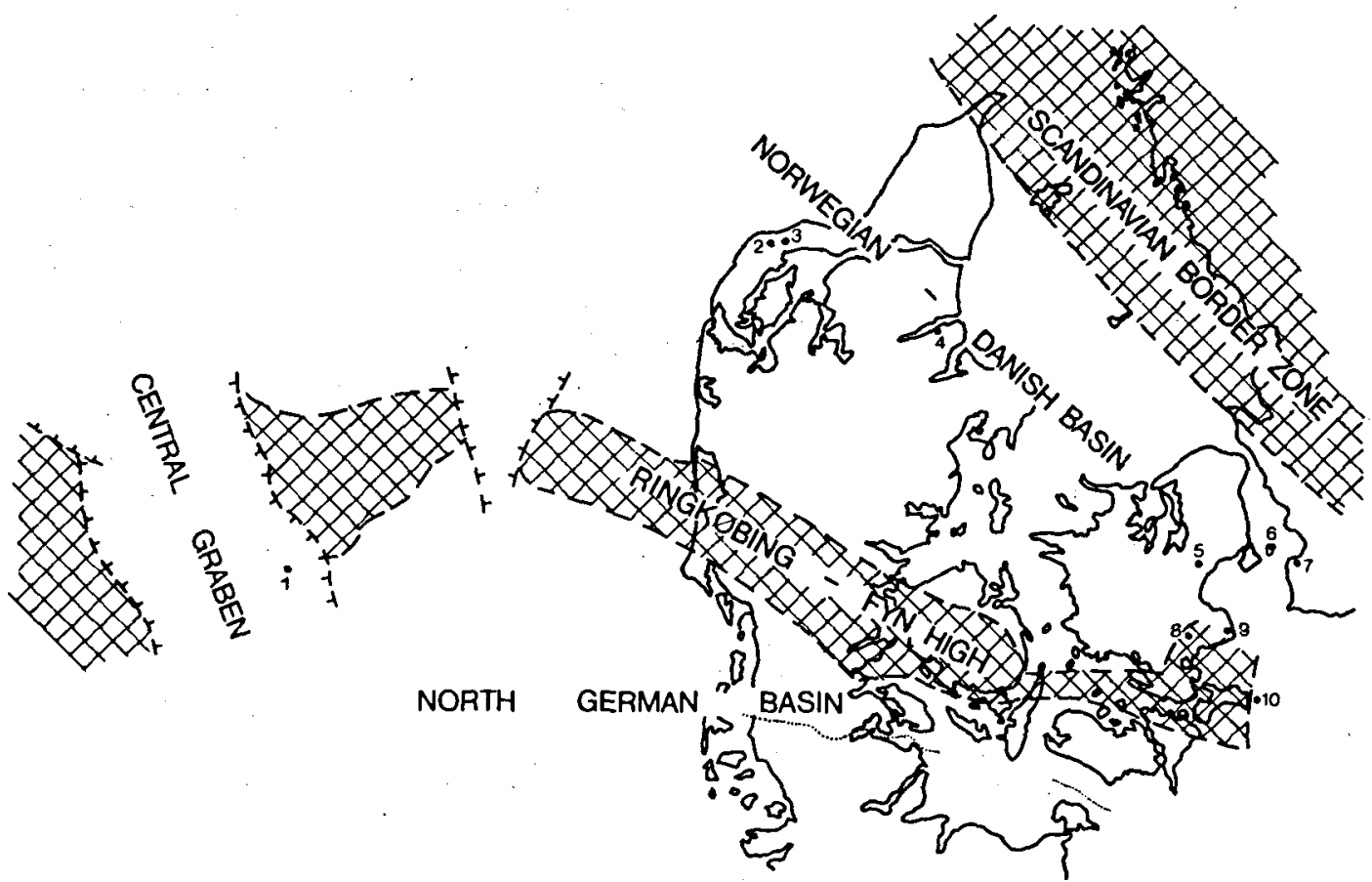

Fig. 1. Map of Denmark and the North Sea showing the localities studied. 1: M-1x; 2: Bjerre; 3: Hillerslev; 4: Dania; 5: Karlstrup; 6: Saltholm; 3: Limhamn; 8: Kongsted; 9: Stevns; 10: Hvidskud. 
reporting isotopic results obtained from 22 samples of chalk representing Maastrichtian and lowermost Danian strata. The material was collected from 10 outcrops and boreholes in the Danish basin and the North Sea Central Graben (fig. 1). The chalk is an extremely pure biogenic carbonate sediment only slightly affected by diagenesis. The content of insoluble residue, primarily quartz and clay minerals, ranges from 1 to $10 \mathrm{wt} \%$. The strontium concentration in the carbonate is relatively constant with $\mathrm{Sr} / \mathrm{Ca}$ ratios varying between $1.60 \times 10^{-3}$ and $2.88 \times 10^{-3}$ (Jørgensen 1975, 1979). In addition to bulk samples individual bryozoan skeletons were analysed.

\section{Isotopic measurements and results}

The mass spectrometer used was a manually run Varian MAT TH5 solid source machine aquipped with a TTY punched tape digital output for off-line evaluation of isotopic ratios. The low content of non-carbonate residue offered the opportunity of measuring the isotopic composition of strontium without previous chemical separation of this element. The sample was dissolved and transferred directly onto the filament using 2 drops of $6 \mathrm{~N} \mathrm{HCl}$. Despite the large amounts of calcium present on the filament, it proved possible to obtain a sufficiently stable emission of strontium to measure the isotopic composition with an error of only 1-4 parts in $10^{4}$. This simple procedure is extremely fast and holds promise for future work on low-residue carbonates. Four measurements on the Eimer and Amend isotopic standard were included in this study. The ${ }^{87} \mathrm{Sr} /{ }^{86} \mathrm{Sr}$ ratio of the Eimer and Amend standard (normalised to 0.1194) averaged 0.70818 with a standard deviation of \pm 0.00007 .

The isotopic ratios measured are given in table 1. For comparison with published data the ratios have been adjusted to a value of 0.7080 for the ${ }^{87} \mathrm{Sr} /{ }^{86} \mathrm{Sr}$ ratio of the Eimer and Amend standard. Deviations from an overall average of 0.7075 are within the range of the analythical error and are not significant. Thus no trend in the ${ }^{87} \mathrm{Sr} /{ }^{86} \mathrm{Sr}$ ratio is indicated for the stratigraphic sequence covered by this study. Furthermore, ratios obtained from bryozoan skeletons are in accordance with those measured on bulk samples.
Table 1. Isotope ratios. The abbreviation $b r$. represents samples of bryozoan skeletal fragments.

\begin{tabular}{|c|c|c|c|}
\hline Sample & ${ }^{87} 7_{\mathrm{Sr}}{ }^{86_{\mathrm{Sr}}}$ & Average & Sirotigrophy \\
\hline $\begin{array}{l}M-1 x, 9 \\
M-1 x, 16 \\
\text { Soltholm } 13 \\
\text { Bjerre } 9\end{array}$ & $\begin{array}{l}0.7073+/-0.0001 \\
0.7074+/-0.0002 \\
0.7074+/-0.0002 \\
0.7075+/-0.0001\end{array}$ & 0.7074 & Donian \\
\hline $\begin{array}{l}\text { Bierre 4 } \\
\text { Bierre 1 } \\
\text { Dania 55, br. } \\
\text { Koristrup } \\
\text { Kalstrup, br. } \\
\text { Stevns } 7 \\
\text { Stevns 7, br. } \\
\text { Limhamn } 835 \\
\text { Limhomn } 834 \\
\text { Hillerslev } 2 \\
\text { Hillerslev 2, br. }\end{array}$ & $\begin{array}{l}0.7076+/-0.0001 \\
0.7076+1 /-0.0001 \\
0.7072+/-0.0002 \\
0.7075+/-0.0001 \\
0.7074+/-0.0003 \\
0.7074+/-0.0001 \\
0.7075+/-0.0002 \\
0.7075+1 /-0.0001 \\
0.7076+1 / 0.0001 \\
0.7074+/-0.0001 \\
0.7077+/-0.0004\end{array}$ & 0.7075 & $\begin{array}{c}\text { Upper } \\
\text { Moostrichtion }\end{array}$ \\
\hline $\begin{array}{l}\text { Hvidskud A6 } \\
\text { Hvidskud AC, br. } \\
\text { Hvidskud B6 } \\
\text { Kongsted } 4 \\
\text { Kongsted } 5 \\
M-1 x, 105 \\
M-1 x, 138\end{array}$ & $\begin{array}{l}0.7075+/-0.0001 \\
0.7075+/-0.0001 \\
0.7075+/-0.0002 \\
0.7076+/-0.0001 \\
0.7074+/-0.0002 \\
0.7078+/-0.0003 \\
0.7076+/-0.0002\end{array}$ & 0.7075 & $\begin{array}{c}\text { Lower } \\
\text { Maastrichtion }\end{array}$ \\
\hline
\end{tabular}

${ }^{87} \mathrm{Sr} /{ }^{86} \mathrm{Sr}$ ratios obtained in the present study agree well with results reported by Peterman et al. (1970) based on a considerable collection of skeletal material from the North American continent, which yielded an average ratio of 0.70755 \pm 0.00011 for the Upper Cretaceous (when adjusted to 0.7080 for the Eimer and Amend standard). Tremba et al. (1975) reported similar ratios $(0.7073$ and 0.7075 , both \pm 0.00012$)$ from un-metamorphosed limestones collected on Euboea, Greece.

\section{Conclusion}

The present measurements on marine carbonate sediments from the Dansih Basin and the North Sea Central Graben support the value of 0.7075 for the ${ }^{87} \mathrm{Sr} /{ }^{86} \mathrm{Sr}$ ratio of ocean water during the Upper Cretaceous. No change in this value is apparent in the investigated samples which represent the time span from the Lower Maastrichtian into the Danian.

Acknowledgements. The project was supported by the Danish Natural Science Research Council. 


\section{Dansk sammendrag}

Strontium isotop sammensætningen i 22 prøver af marine karbonatsedimenter fra det danske Maastrichtian og Danian fremviser særdeles konstante ${ }^{87} \mathrm{Sr} /{ }^{86} \mathrm{Sr}$ forhold. Den beregnede middelværdi på 0.7075 bekræfter tidligere publicerede målinger af strontium isotop forholdet $i$ oceanisk havvand fra $\emptyset v r e$ Kridt. Der er desuden ikke påvist nogen signifikant forskel mellem strontium isotop forholdet $i$ karbonatsedimentet og skeletfragmenter af bryozoer fra samme prove.

\section{References}

Faure, G., Assereto, R. \& Tremba, E. L. 1978: Strontium isotope composition of marine carbonates of Middle Traissic to Early Jurassic age, Lombardic Alps, Italy. Sedimentology 25, 523-543.
Jørgensen, N. O. 1975: $\mathrm{Mg} / \mathrm{Sr}$ distribution and diagenesis of Maastrichtian white chalk and Danian bryozoan limestone from Jylland, Denmark. Bull. geol. Soc. Denmark 24, 299-325.

Jørgensen, N. O. 1979: $\mathrm{Mg}$ and $\mathrm{Sr}$ distribution in carbonate rocks in the boundary sequence in the Danish Basin and the North Sea Central Graben. In Birkelund \& Bromley (eds): Cretaceous - Tertiary Boundary Events I, 33-41. University of Copenhagen 1979.

Peterman, Z. E, Hedge, C. E. \& Tourtelot, H. A. 1970: Isotopic composition of strontium in sea water throughout Phanerozoic time. Geochim. Cosmochim. Acta 34, $105-120$.

Tremba, E. L., Faure, G., Katsikatsos, G. C. \& Summerson, C. H. 1975: Strontium-isotope composition in the Thetys Sea, Euboea, Greece. Chem. Geol. 16, 109-120.

Veizer, J. \& Compston, W. $1974:{ }^{87} \mathrm{Sr} /{ }^{86} \mathrm{Sr}$ composition of seawater during the Phanerozoic. Geochim. Cosmochim. Acta 38, 1461-1484. 